\title{
Can Seaweed Farming Play a Role in Climate Change Mitigation and Adaptation?
}

\author{
Carlos M. Duarte ${ }^{1,2,3 *}$, Jiaping $\mathrm{Wu}^{4}$, Xi Xiao ${ }^{4}$, Annette Bruhn ${ }^{2}$ and Dorte Krause-Jensen ${ }^{2,3}$ \\ ${ }^{1}$ Red Sea Research Center, King Abdullah University of Science and Technology, Thuwal, Saudi Arabia, ${ }^{2}$ Department of \\ Bioscience, Aarhus University, Silkeborg, Denmark, ${ }^{3}$ Arctic Research Centre, Aarhus University, Silkeborg, Denmark, ${ }^{4}$ Ocean \\ College, Zhejiang University, Zhoushan, China
}

\section{OPEN ACCESS \\ Edited by:}

Gretchen E. Hofmann University of California, Santa Barbara,

Reviewed by:

Michael Yu Roleda, Norwegian Institute of Bioeconomy

Research, Norway Stein Fredriksen, University of Oslo, Norway

*Correspondence: Carlos M. Duarte carlos.duarte@kaust.edu.sa

Specialty section:

This article was submitted to Global Change and the Future Ocean, a section of the journal Frontiers in Marine Science

Received: 27 November 2016 Accepted: 24 March 2017 Published: 12 April 2017

Citation:

Duarte CM, Wu J, Xiao X, Bruhn A and Krause-Jensen D (2017) Can Seaweed Farming Play a Role in Climate Change Mitigation and Adaptation? Front. Mar. Sci. 4:100 doi: 10.3389/fmars.2017.00100
Seaweed aquaculture, the fastest-growing component of global food production, offers a slate of opportunities to mitigate, and adapt to climate change. Seaweed farms release carbon that maybe buried in sediments or exported to the deep sea, therefore acting as a $\mathrm{CO}_{2}$ sink. The crop can also be used, in total or in part, for biofuel production, with a potential $\mathrm{CO}_{2}$ mitigation capacity, in terms of avoided emissions from fossil fuels, of about 1,500 tons $\mathrm{CO}_{2} \mathrm{~km}^{-2}$ year ${ }^{-1}$. Seaweed aquaculture can also help reduce the emissions from agriculture, by improving soil quality substituting synthetic fertilizer and when included in cattle fed, lowering methane emissions from cattle. Seaweed aquaculture contributes to climate change adaptation by damping wave energy and protecting shorelines, and by elevating $\mathrm{pH}$ and supplying oxygen to the waters, thereby locally reducing the effects of ocean acidification and de-oxygenation. The scope to expand seaweed aquaculture is, however, limited by the availability of suitable areas and competition for suitable areas with other uses, engineering systems capable of coping with rough conditions offshore, and increasing market demand for seaweed products, among other factors. Despite these limitations, seaweed farming practices can be optimized to maximize climate benefits, which may, if economically compensated, improve the income of seaweed farmers.

\section{Keywords: seaweed, aquaculture, carbon dioxide, macroalgae, sequestration, climate change}

\section{INTRODUCTION}

With an annual production of 27.3 million tons in 2014 and a growth rate of $8 \%$ year $^{-1}$, seaweed aquaculture now comprises $27 \%$ of total marine aquaculture production. Still the value of the seaweed produced only amounts to $5 \%$ of the total value of aquacultural crops (FAO, 2016a). Looking at the process chain of seaweed from production through processing to final products, the growth of the actual seaweed production lags behind the demand of biomass for the many traditional and novel applications for this expanding crop (Mazarrasa et al., 2014; Callaway, 2015). Further expansion of seaweed aquaculture will require development of a skilled labor force and new technologies to occupy additional suitable areas for farming. Also a diversification of applications will make the industry more resilient to impacts derived from shifting demands from specific industries. A closer synergy between further expansion of seaweed aquaculture and the development of novel demands for this crop will be essential to continue to fuel the growth of this emerging blue industry (Mazarrasa et al., 2014). Compensating farmers for the role of seaweed production in climate change mitigation and adaptation need also be considered. Indeed, an increased 
contribution of seaweed aquaculture to climate change mitigation and adaptation requires that seaweed production continues to grow. However, further growth of seaweed production may drive market prices down, in turn discouraging farmers from engaging in this activity. Thus, providing economic incentives associated with the benefits for climate change mitigation and adaptation may be instrumental in supporting increased seaweed production into the future.

Seaweed production, both from wild stocks and from aquaculture, represents an important conduit for $\mathrm{CO}_{2}$ removal from the atmosphere, with strongly autotrophic seaweed communities globally taking up $1.5 \mathrm{Pg} \mathrm{C}_{\text {year }}{ }^{-1}$ via their netproduction (Krause-Jensen and Duarte, 2016). Yet, the potential of managing seaweed production to mitigate climate change by sequestering $\mathrm{CO}_{2}$ has not yet been fully incorporated into the emergent concept of Blue Carbon, referring to climate change mitigation strategies based on the capacity of marine plants to bind $\mathrm{CO}_{2}$ (Nellemann et al., 2009; McLeod et al., 2011; Duarte et al., 2013). The reason for such neglect is the belief that the large majority of seaweed production is decomposed in the ocean and therefore, does not represent a net sink for $\mathrm{CO}_{2}$. However, this view has been recently challenged (Hill et al., 2015; Trevathan-Tackett et al., 2015; Moreira and Pires, 2016) and new evidence suggests that seaweeds are globally-relevant contributors to oceanic carbon sinks (Krause-Jensen and Duarte, 2016). Hence, the contribution of seaweed to Blue Carbon and climate change mitigation strategies is now being reconsidered.

One pathway to broaden Blue Carbon strategies to incorporate the $\mathrm{CO}_{2}$ sink capacity of seaweeds is to manage the fate of seaweed production, whether derived from aquaculture or harvest of wild stocks, to reduce $\mathrm{CO}_{2}$ emissions derived from fossil fuel use. This can be achieved, for instance, through the use of seaweed biomass as biofuel directly replacing fossil fuels (e.g., Kraan, 2013; Chen et al., 2015), and/or replacing food or feed production systems with intense $\mathrm{CO}_{2}$ emission footprints by seaweed-based food systems, which have much lower lifecycle $\mathrm{CO}_{2}$ emission (Fry et al., 2012). Indeed, a seaweed-based Blue Carbon program has been developed in Korea (Chung et al., 2013; Sondak and Chung, 2015), providing an initial step in this direction. Yet, Korea contributes only $6 \%$ of global seaweed aquaculture production (FAO, 2016b), so the development of seaweed farming as a Blue Carbon strategy for climate change mitigation would require that major producers, such as China accounting for more than half of the global seaweed aquaculture production, engage with this strategy.

The development of seaweed farming as a strategy for climate change mitigation would help alleviate present constraints on the further growth of seaweed aquaculture. Growth of seaweed production is exceeding that of traditional markets, leading to a steady decline in price at about $1-2 \%$ year $^{-1}$ (Kronen et al., 2013), deterring farmers and investors from engaging. Economic compensation for the environmental benefits brought about by seaweed farming, including its role in climate change mitigation, would allow for further growth and a more sustainable seaweed aquaculture industry. In particular, economic compensation for climate services associated with seaweed farming would help generate a new market for seaweed production while also creating incentives to reduce further the life-cycle $\mathrm{CO}_{2}$ emissions of seaweed aquaculture.

Here we outline the potential to develop seaweed Blue Carbon Farming as a strategy for climate change mitigation and adaptation. We do so by first assessing the potential, based on wild and aquaculture production, and the pathways for this production to be managed as to result in avoidance of $\mathrm{CO}_{2}$ emissions while possibly generating climate change adaptation co-benefits. We then evaluate the role of seaweed aquaculture in adaptation to specific impacts of climate change in the marine environment, such as ocean acidification, deoxygenation, and shoreline erosion (e.g., Gattuso et al., 2015). Finally, we propose a number of actions required to consolidate such program as a component of the pathway to solutions for climate change adaptation and mitigation.

\section{GLOBAL SEAWEED PRODUCTION AND THE ASSOCIATED $\mathrm{CO}_{2}$ UPTAKE}

Seaweed communities are strongly autotrophic, generating far more organic matter through photosynthesis than consumed by respiration in the ecosystem, and are thus responsible for much of $\mathrm{CO}_{2}$ capture in marine vegetated habitats (Duarte and Cebrian, 1996). An upper limit to the $\mathrm{CO}_{2}$ capture potential of seaweed aquaculture can be calculated at 2.48 million tons of $\mathrm{CO}_{2}(0.68 \mathrm{Tg}$ C) per year. This upper limit assumes that all of the 27.3 million tons fresh weight produced in 2014 be dedicated to carbon capture with a $100 \%$ yield given by the average carbon content of $24.8 \%$ of seaweed dry weight (Duarte, 1992) and a conservative dry weight:fresh weight ratio of 0.1 . However, even this upper limit constitutes only about $0.4 \%$ of the global wild seaweed $\mathrm{CO}_{2}$ capture estimated at $173 \mathrm{Tg} \mathrm{C}$ year $^{-1}$ (Krause-Jensen and Duarte, 2016). At current growth rates, the upper limit to the $\mathrm{CO}_{2}$ capture potential of seaweed aquaculture would exceed $6 \%$ of the global $\mathrm{CO}_{2}$ sequestration by wild seaweed by 2,050 . Hence, $\mathrm{CO}_{2}$ capture by seaweed aquaculture alone cannot represent a major underpinning of emission reduction programs with the current and even projected potentials. However, these comparisons are based on quantities spread over hugely different areas. The 173 Tg C year ${ }^{-1}$ sequestered by wild seaweed is spread over the entire ocean, as most of this sequestration occurs in the deep sea, and the carbon supporting this flux is produced over the 3.5 million $\mathrm{km}^{2}$ occupied by seaweed (Krause-Jensen and Duarte, 2016). In contrast, the area occupied by seaweed aquaculture, calculated from a typical yield of seaweed aquaculture of 1,604 tons DW $\mathrm{km}^{-2}$ (The Fishery Bureau MoA, 2015), represents only about $1,600 \mathrm{~km}^{2}$ globally, i.e., $0.04 \%$ of the area covered by wild seaweed habitats or about $0.004 \%$ of the global extent of agricultural land (43 million $\mathrm{km}^{2}$ in 2,000, Ramankutty et al., 2008). Hence, whereas seaweed aquaculture does not yet have a scale that would support a global role in climate change mitigation, it has a strong potential $\mathrm{CO}_{2}$ sequestration intensity of about 1,500 tons $\mathrm{CO}_{2}$ $\mathrm{km}^{-2}$ year ${ }^{-1}$, corresponding to the annual $\mathrm{CO}_{2}$ emissions of about 300 Chinese citizens.

Whereas, seaweed aquaculture currently occupies a minimal fraction, $0.004 \%$, of the coastal ocean, the scope for expansion 
may be limited by the availability of suitable areas and competing demands for suitable space, and face constraints due to limits to seaweed production imposed by nutrient availability as well as shifting temperature regimes. Current technology for seaweed aquaculture, based on simple structures, can be deployed only in relatively sheltered areas, which will restrict the industry to a fraction of the potential area. Whereas, the effects of climate change on macroalgal cultivation are not yet clear (Callaway et al., 2012), ocean warming may reduce fucoid canopies through physiological stress as well as additional associated pressures from warm-water herbivores (Harley et al., 2012), increased storm energy and reduced nutrient supply (Callaway et al., 2012), possibly reducing seaweed aquaculture yields. Species cultured at latitudes close to their thermal limits may be impacted by further warming, whereas warming may increase the yield in areas where temperature or ice cover may limit current production, such as predicted for the Arctic (Krause-Jensen and Duarte, 2014). In addition, increased $\mathrm{CO}_{2}$ may increase the yield of seaweed aquaculture (Callaway et al., 2012). Lastly, the expansion of seaweed aquaculture need also consider potential impacts, such as the introduction of invasive species. However, assessment of the impacts of invasive seaweed species, derived from aquaculture (e.g., Undaria pinnatifida), report both benefits and impacts, which are not severe in nature (McLaughlan et al., 2014).

Despite the limitations acknowledged above, the scope for expansion of seaweed aquaculture with available structures and constraints is substantial. Gattuso et al. (2006) calculated the potential coastal area marine macrophytes may occupy, on the basis of the assessment of their light requirements and light availability, to be $5.71 \times 10^{6} \mathrm{~km}^{2}$ in the non-polar regions. However, this estimate is based on the light reaching the seafloor, whereas seaweed aquaculture is based on algae suspended near the surface, thereby overcoming issues of light limitation. For instance, Norway has assessed that seaweed aquaculture can markedly stimulate the Norwegian bio-economy (Skjermo et al., 2014) by expanding seaweed aquaculture along its extensive $\left(90,000 \mathrm{~km}^{2}\right)$ and productive economic zone from current negligible levels to $20 \times 10^{6}$ tons by 2,050 (Olafsen et al., 2012). The surface area occupied by seaweed cultivation has more than tripled the Norwegian coast in only 3 years along (2014 and 2016, Stévant et al., 2017). Moreover, the scope for expansion of seaweed aquaculture beyond the currently suitable areas may be facilitated in the future by developments in offshore aquaculture, allowing cultivation (e.g., Sulaiman et al., 2015) and seaweed biorefining (Fernand et al., in press) in offshore farms (Lehahn et al., 2016). Current marine spatial models already propose solutions to competing demands for suitable space, such as the co-location of offshore wind farms and seaweed aquaculture (Gimpel et al., 2015).

However, calculations of the $\mathrm{CO}_{2}$ removal potential with seaweed aquaculture also need consider the energy consumption of seaweed farming. Life cycle analyses have concluded that the net removal of $\mathrm{CO}_{2}$ from the atmosphere by biofuel production from seaweed aquaculture is about $961 \mathrm{~kg} \mathrm{CO} 2$ per ton DW of seaweed (Alvarado-Morales et al., 2013). The potential $\mathrm{CO}_{2}$ sequestration intensity of seaweed farms of about 1,500 tons $\mathrm{CO}_{2} \mathrm{~km}^{-2}$ year ${ }^{-1}$ is somewhat above $10 \%$ of the $\mathrm{CO}_{2}$ emissions avoided by offshore wind farms of about 12,500 tons $\mathrm{CO}_{2} \mathrm{~km}^{-2}$ year ${ }^{-1}$. The $\mathrm{CO}_{2}$ emissions avoided per unit area by offshore wind farms were derived by dividing the $\mathrm{CO}_{2}$ avoidance of wind farms by the area occupied by the farms, corrected for a $2 \%$ lifecycle $\mathrm{CO}_{2}$ emissions over a nominal 20 year life span of the turbines (Martínez et al., 2009). The calculations were based on data for the Sanbanks offshore wind farms (Germany, 21 turbines in $61 \mathrm{~km}^{2}$, Vattenfall, 2016) $)^{1}$ and for the LINCS offshore wind farms (UK, 83 turbines in $35 \mathrm{~km}^{2}$, Centrica Energy, 2007).

Clearly, the comparison above would suggest that seaweed aquaculture cannot be the option of choice if the sole intent is to mitigate climate change. However, establishing a seaweed farm in some areas of the world is rather inexpensive, requiring for instance an initial investment of $<$ US \$15,000 for a 1 ha seaweed farm in Mexico (Robledo et al., 2013), whereas the cost of a state-of-the-art offshore wind turbine, including installation, is about US \$ 1.5 million per turbine, and involves order-ofmagnitude larger maintenance costs. Hence, many developing nations cannot afford addressing climate change mitigation through high-cost solutions, such as off-shore wind farms, but can indeed establish seaweed farms, and thereby in addition to climate mitigation, they will be producing a valuable biomass with potential for delivering food, feed, biomolecules, and energy http://www.fao.org/docrep/field/003/AC287E/AC287E01.htm (Msuya, 2011; Rebours et al., 2014). Moreover, "blue” biofuels, such as seaweed biofuels, do not compete for resources with agriculture, as they do not require arable land, freshwater or fertilizer, herbicide or pesticide applications and are, therefore in many respects, more environmentally sustainable than current biofuels derived from land crops (Duarte et al., 2009, 2013). Calculations of the area required for seaweed aquaculture to supply $60 \%$ of the transportation fuel vary broadly, from $<1 \%$ of the economic exclusive zone (EEZ) for Norway, to $10 \%$ of the Dutch EEZ and about twice of the German EEZ (Fernand et al., in press). The option to expand seaweed aquaculture by increasingly occupying offshore areas is not without challenges, including new engineering designs to withstand rough sea states as well as additional costs, and energy use, involved in transporting the crops and operators across greater distances (Fernand et al., in press). Further, as nutrient concentrations typically decrease offshore, nutrient availability may impose constraints on seaweed aquaculture yield in offshore farms (Fernand et al., in press).

A stepwise approach to maximizing the benefits from seaweed aquaculture would include to sequentially extract high-value molecules used in the food, pharma or biotech industries, such as bioactive sulphated polysaccharides, pigments, and antioxidants (D’Orazio et al., 2012; Mak et al., 2014; Herrero and Ibáñez, 2015), and then convert-after extraction of carbohydrates for the hydrocollid industry or for biofuels production-the lowervalue residue to protein concentrates with value in the feed industry (Francavilla et al., 2015; Bikker et al., 2016; Seghetta et al., 2016). Algal biorefineries have evolved from concept and laboratory tests to pilot-scale plants involving a range of seaweed species and environments (e.g., Baghel et al., 2014; Lorbeer et al.,

${ }^{1}$ Available online at: https://corporate.vattenfall.com/about-energy/renewableenergy-sources/wind-power/wind-power-at-vattenfall/). 
2015; Bikker et al., 2016; Masarin et al., 2016), and may soon become commercial operations. The range of potential products also include using the nutrient-rich residues from a biofuel production for fertilizer, which may also serve for $\mathrm{C}$ retention in soil (Seghetta et al., 2016). New bioenergy concepts also use seaweed by-products and debris in energy production (Kaspersen et al., 2016).

Seaweed farms also act as a source of DOC and POC exported to adjacent locations, where some of this carbon may be buried (Zhang et al., 2012). We recently summarized 105 reports of sequestration of seaweed to carbon sequestration in sediments or the deep sea, and showed that $25 \%$ of the carbon exported from macroalgal stands, which represents about $43 \%$ of their net primary production, is sequestered in continental shelf sediments or in the deep-sea (Krause-Jensen and Duarte, 2016). A fraction of the organic carbon exported from seaweed farms is also ultimately sequestered in sediments or exported to the deep sea (e.g., Zhang et al., 2012), further supporting the role of seaweed farms in climate change mitigation. However, as seaweed grown in aquaculture is harvested, the fraction of its net primary production available to be sequestered is likely smaller than that of wild seaweed stands. Whereas, most macroalgal stands grow on rocky shores, thereby requiring the export of carbon to depositional sites to contribute to carbon sequestration (Krause-Jensen and Duarte, 2016), seaweed farms can be placed over soft sediments, where detritus could be buried. The processes conducive to sequestration are, otherwise, similar to those operating in wild seaweed stands, including export with ocean currents during storms and/or tidal currents, transport to the deep-sea along submarine canyons, and sinking of exported seaweed material ballasted by epiphytes and/or stones attached to their holdflasts (Krause-Jensen and Duarte, 2016).

Even where food production, and not climate change mitigation, is the main goal of seaweed farming, benefits in terms of climate change mitigation can be substantial. The reason for this is that the $\mathrm{CO}_{2}$ emissions involved in producing seaweed aquaculture are much less than those involving in producing a comparable amount of agriculture products on land. Agriculture is responsible for about 30\% of greenhouse gas emissions, resulting from land-use change in conversion of wild ecosystems into croplands, intense emissions associated with the production and application of industrial fertilizers and emissions from cattle (Robertson et al., 2000; Smith, 2002). Seaweed aquaculture generates food while minimizing the impacts associated with land-based food production systems (e.g., Duarte et al., 2009). For instance, recent in vitro experiments showed that fermentation of seaweed, simulating that of ruminant digestion, substantially reduced methane emissions (Kinley et al., 2016; Maia et al., 2016), and that addition of only $2 \%$ of specific seaweed species to the diet of cattle could reduce the methane emission from cattle production by 99\% (Machado et al., 2016). Indeed, ruminants were traditionally fed seaweed in many coastal regions during periods of feed scarcity, but the potential benefits in terms of reduced methane emissions have only recently been realized (Kinley et al., 2016; Maia et al., 2016). Hence, supplementing feed for ruminant cattle with seaweed holds a potential to reduce methane emissions, a possibility that, if confirmed by in vivo and farm-scale experiments, could greatly contribute to mitigate emissions of this powerful greenhouse gas. Prebiotic compounds and essential minerals in seaweeds may furthermore help to enhance livestock production and health (Rey-Crespo et al., 2014; Makkar et al., 2016), as well as substitute the use of antibiotics in the intensive livestock production (O'Doherty et al., 2010; O'Shea et al., 2014). An additional potential benefit of seaweed farming for agriculture is a reported increase in productivity of crops via soil amelioration by nutrient-rich seaweed biochar (Roberts et al., 2015; Zacharia et al., 2015) or seaweed compost (Cole et al., 2016), thereby avoiding emissions involved in synthetic fertilizer production (Smith, 2002). Yet, it is unlikely that seaweed aquaculture will comprise a sizeable fraction of vegetable production on land, particularly as food demand is growing with increasing human population.

\section{BENEFITS OF SEAWEED AQUACULTURE FOR CLIMATE CHANGE ADAPTATION}

The IPCC defines climate change adaptation as the process of adjustment to actual or expected climate and its effects (IPCC, 2014). In human systems, adaptation seeks to moderate or avoid harm or exploit beneficial opportunities whereas in natural systems it refers to human intervention to facilitate its adjustment to expected climate and its effects (IPCC, 2014). In this context, we address the use of seaweed aquaculture for climate change adaptation in terms of its capacity to avoid harms to human systems (e.g., coastal protection, ensure food security) and vulnerable ecosystems (e.g., provide refugia from ocean acidification and ocean deoxygenation).

By creating coastal habitats, seaweed aquaculture can potentially contribute some of the ecosystem functions that natural kelp forests and macroalgal beds support (Smale et al., 2013). Some of these functions contribute, as mentioned above, to mitigate climate change while another set of functions have climate change adaptation benefits (Figure 1, cf. Duarte et al., 2013). For example, the canopies of farmed seaweeds, like those of wild seaweeds, dampen wave energy and hence, serve as live coastal protection structures buffering against coastal erosion (Mork, 1996; Løvås and Tørum, 2001). Norwegian kelp forests dominated by Laminaria hyperborea have been reported to reduce wave heights by up to $60 \%$ (Mork, 1996). A key difference, in terms of the capacity of farmed seaweed to reduce wave energy is that their canopies are suspended from the surface rather than being benthic. The wave-attenuating effect depends on the extent and structure of the seaweed habitat (Gaylord et al., 2007) as well as the energy involved as seaweed farms will be damaged during high-energy storms.

Dense seaweeds, farmed as well as wild, also represent productivity hot-spots with associated high $\mathrm{pH}$ during day when photosynthesis reduces $\mathrm{CO}_{2}$ concentrations (e.g., Middelboe and Hansen, 2007; Krause-Jensen et al., 2015). They may, hence, serve a role in protecting calcifies from projected ocean acidification (Krause-Jensen et al., 2015). Kelp forests support high biodiversity, including calcifiers such as lobsters, crabs, molluscs, and crustaceans (Steneck et al., 2002; Smale et al., 


\section{SEAWEED FARMING AND CLIMATE CHANGE \\ MITIGATION VIA: \\ ADAPTATION TO:}

Ongoing processes:

C-sequestration

via export of "unseen" production

Food production

with reduced $\mathrm{CO}_{2}$ foot print

Future potentials:

Bioenergy production

substituting fossil fuels

Reduction of methane emission

via seaweed feed additive to ruminants

Stimulation of land-based production

via seaweed biochar soil amelioration \&

seaweed prebiotic health benefits to livestock

\section{Climate benefit of circular nutrient management \\ Via avoidance of $\mathrm{CO}_{2}$ emissions for synthetic} fertiliser production
Increased storminess and sea

level rise

Shoreline protection via

dissipation of wave energy

Ocean Acidification

High daytime $\mathrm{pH}$ in seaweed to

the benefit of calcifiers

Oxygen inputs to coastal

waters

Avoiding ocean deoxygenation

with warming

FIGURE 1 | Overview of key climate change mitigation- and adaptation benefits of seaweed farming. Photo: Yngvar Olsen.

2013) and high daytime $\mathrm{pH}$ probably contributes to this effect. Seaweed farms are similarly reported to support high biodiversity (Radulovich et al., 2015). As day-periods of high productivity and $\mathrm{pH}$ in seaweed habitats can alternate with night-periods where respiration creates reduced pH (Delille et al., 2009), the potential for $\mathrm{pH}$-upregulation and associated effects of seaweeds as refugia for calcifiers should increase with photoperiod. Indeed, during midsummer near the poles where photoperiods exceed 21 $\mathrm{h}$, seaweed productivity can create sustained high $\mathrm{pH}$ over the summer period and be particularly suitable habitats for calcifiers (Krause-Jensen et al., 2016). The capacity of seaweed aquaculture to affect $\mathrm{pH}$ and provide refugia for calcifiers depend also on flow regimes (Hurd, 2015) and increase where the farms are located in coastal environment with weak currents and/or where the seaweed themselves slow down flow. The capacity of seaweed farms to offer habitat for biodiversity is, however, temporary, as this capacity is lost at harvest.

Ocean de-oxygenation with warming is also a component of climate change impacts in the ocean of mounting concern (Keeling et al., 2010), particularly for eutrophic coastal areas, which are particularly prone to experience hypoxia (Diaz and Rosenberg, 2008). Seaweed aquaculture results in more autotrophic ecosystems than even those supported by wild seaweed, because the production is harvested, and is, therefore, removed from being remineralized, consuming oxygen, in the ecosystem. Hence, seaweed farms provide oxygen-rich habitats, providing refugia from hypoxia and declining oxygen levels, further contributing to allow marine organisms to adapt to this component of a warmer ocean.

\section{SPATIAL PLANNING TO MAXIMIZE SEAWEED BLUE CARBON FARMING}

Maximizing the climate change mitigation impact of seaweed farming also requires that the farms exert no negative impact on natural coastal carbon stocks, particularly those associated with seagrass meadows. Seagrass meadows are hot-spots of carbon sequestration and hence, key Blue Carbon habitats (Duarte et al., 2005, 2013; McLeod et al., 2011; Fourqurean et al., 2012). They are vulnerable to human disturbance leading to shading and mechanical damage (Waycott et al., 2009), both of which could result from activities at neighboring seaweed farms. On the other hand, nutrient removal by seaweed farms can improve water quality and allow recovery of seagrass in severely eutrophied areas.

Of course the placement of seaweed farms must also consider the habitat requirements of the cultured seaweed (Kerrison et al., 2015) as well as habitat conditions optimizing the quality of the crop for the targeted use (Bruhn et al., 2016). Additional environmental benefits may arise from choosing areas already enriched in nutrients, including use in polycultures to reduce nutrient impacts of animal aquaculture. While seaweed farming under eutrophic conditions may increase the yield of some crops, 
it can represent a severe challenge for other crops such as kelp, which risks overgrowth by epiphytes and hence thrive better at less eutrophic sites with sufficient water flow to replenish nutrients, $\mathrm{CO}_{2}$, and oxygen, and limit epiphytic growth (Bruhn et al., 2016).

Locating seaweed farms in areas under particular risk from climate change impacts, such as low-lying coastal areas, vulnerable to flooding during storms with increasing sea level, areas prone to exposure to acidified and/or oxygen-depleted waters, may provide a tactical approach to enhance the benefits of seaweed aquaculture for climate change adaptation. However, these, and other, environmental conditions also place constraints on the type of seaweed that can be grown as well as the possible products that can be derived from the farm.

Spatial planning of seaweed aquaculture to mitigate climate change should also seek to minimize life-cycle $\mathrm{CO}_{2}$ emissions by co-locating farming and processing, and covering energy requirements by renewable energy where possible. In addition, spatial planning is required to minimize negative interactions with other uses of the coastal zone, such as navigation, as well as to minimize environmental impacts from seaweed aquaculture.

\section{CONCLUSION}

The discussion above provides a suite of arguments supporting the consideration of seaweed aquaculture as a tool for climate change mitigation and adaptation, while also identifying possible caveats and limitations. Indeed, the growing seaweed aquaculture industry is already delivering these benefits, which have not been properly accounted for nor have been credited to seaweed farmers. Because of the very low investment required to set up seaweed aquaculture farms, seaweed aquaculture is a particularly sound strategy for coastal developing nations to contribute to climate change mitigation while protecting their shoreline and marine ecosystems from some of the effects of climate change, such as ocean acidification and ocean de-oxygenation. Constraints for the expansion of the climate mitigation and adaptation benefits associated with seaweed aquaculture are multiple. In the case of China, the main challenges are competition for suitable space with other uses and the maintenance of a sufficient profit margin to continue to engage farmers. More generically, the constraints involve physical constraints, such as the availability of suitable areas; regulatory constraints, such as the requirements for concessions for

\section{REFERENCES}

Alvarado-Morales, M., Boldrin, A., Karakashev, D. B., Holdt, S. L., Angelidaki, I., and Astrup, T. (2013). Life cycle assessment of biofuel production from brown seaweed in Nordic conditions. Biores. Technol. 129, 92-99. doi: 10.1016/j.biortech.2012.11.029

Baghel, R. S., Reddy, C. R. K., and Jha, B. (2014). Characterization of agarophytic seaweeds from the biorefinery context. Bioresour. Technol. 159, 280-285. doi: 10.1016/j.biortech.2014.02.083

Bikker, P., Krimpen, M. M., Wikselaar, P., Houweling-Tan, B., Scaccia, N., Hal, J. W., et al. (2016). Biorefinery of the green seaweed Ulva lactuca to seaweed aquaculture; marine spatial planning constraints, such as competition for space with other marine-based activities; and market constraints, such as the existence of demand for seaweed aquaculture products, necessary to maintain a profit margin that may motivate prospective farmers to engage. Promoting seaweed aquaculture as a component of climate change mitigation and adaptation strategies requires that all four dimensions of the social-ecological system that supports seaweed aquaculture (cf. Broitman et al., 2017) be addressed: (1) biological productivity to enhance carbon capture, (2) environment constraints to the expansion of seaweed aquaculture, (3) policy tools that enable seaweed aquaculture, and (4) manage societal preferences and markets demands for seaweed products. Maintaining a market price that encourages seaweed farmers to engage and implement design improvements to maximize climate services delivered by the farm requires that markets diversify to increase the demand for seaweed products. Subsidizing farmers, either directly or indirectly through tax abatement, for farms credited as blue carbon seaweed farms may further increase engagement with this strategy. While the contribution of seaweed aquaculture to climate change mitigation and adaptation will remain globally modest, it may be substantial in developing coastal nations and will provide add-on value to the societal benefits derived from seaweed aquaculture.

\section{AUTHOR CONTRIBUTIONS}

$\mathrm{CD}$ and $\mathrm{DK}$ conceived and wrote the piece. $\mathrm{AB}, \mathrm{XX}$, and JW contributed to the concept and writing. All authors approved the submission.

\section{ACKNOWLEDGMENTS}

This research was supported by King Abdullah University of Science and Technology (KAUST) through the baseline fund to $\mathrm{CD}$. $\mathrm{AB}$ was supported by the MacroAlgae Biorefinery 4 (MAB4) and the Macrofuels projects, funded by the Innovation Fund Denmark and the European Union's Horizon 2020 research and innovation programme under grant agreement No 654010, respectively. DK received financial support from the COCOA project under the BONUS programme, which is funded by the EU 7th Framework Programme and the Danish Research Council. JW and XX were supported by the International Science and Technology Cooperation Program of China (Grant No. 2015DFA01410). produce animal feed, chemicals and biofuels. J. Appl. Phycol. 28, 3511-3525. doi: 10.1007/s10811-016-0842-3

Broitman, B. R., Halpern, B. S., Gelcich, S., Lardies, M. A., Vargas, C. A. Vásquez-Lavín, F., et al. (2017). Dynamic interactions among boundaries and the expansion of sustainable aquaculture. Front. Mar. Sci. 4:15. doi: $10.3389 /$ fmars.2017.00015

Bruhn, A., Tørring, D. B., Thomsen, M., Canal-Vergés, P., Nielsen, M. M., Rasmussen, M. B., et al. (2016). Impact of environmental conditions on biomass yield, quality, and bio-mitigation of Saccharina latissima. Aquac. Environ. Interact. 8, 619-636. doi: 10.3354/aei 00200 
Callaway, E. (2015). Lab staple agar hit by seaweed shortage. Nature 528, 171-172. doi: $10.1038 / 528171 \mathrm{a}$

Callaway, R., Shinn, A. P., Grenfell, S. E., Bron, J. E., Burnell, G., Cook, E. J., et al. (2012). Review of climate change impacts on marine aquaculture in the UK and Ireland. Aquat. Conserv. Mar. Freshwater Ecosyst. 22, 389-421. doi: $10.1002 /$ aqc. 2247

Centrica Energy (2007). Available online at: http://www.eib.org/infocentre/ register/all/53219469.pdf

Chen, H., Zhou, D., Luo, G., Zhang, S., and Chen, J. (2015). Macroalgae for biofuels production: progress and perspectives. Renew. Sust. Energ. Rev. 47, 427-437. doi: 10.1016/j.rser.2015.03.086

Chung, I. K., Oak, J. H., Lee, J. A., Shin, J. A., Kim, J. G., and Park, K.-S. (2013). Installing kelp forests/seaweed beds for mitigation and adaptation against global warming: Korean Project Overview. ICES J. Mar. Sci. 70, 1038-1044. doi: 10.1093/icesjms/fss206

Cole, A. J., Roberts, D. A., Garside, A. L., de Nys, R., and Paul, N. A. (2016). Seaweed compost for agricultural crop production. J. Appl. Phycol. 28, 629-642. doi: 10.1007/s10811-015-0544-2

Delille, B., Borges, A. V., and Delille, D. (2009). Influence of giant kelp beds (Macrocystis pyrifera) on diel cycles of $\mathrm{pCO}_{2}$ and DIC in the Sub-Antarctic coastal area. Estuar. Coast. Shelf Sci. 81, 114-122. doi: 10.1016/j.ecss.2008.10.004

Diaz, R. J., and Rosenberg, R. (2008). Spreading dead zones and consequences for marine ecosystems. Science 321, 926-929. doi: 10.1126/science.1156401

D’Orazio, N., Gemello, E., Gammone, M. A., de Girolamo, M., Ficoneri, C., and Riccioni, G. (2012). Fucoxanthin: a treasure from the sea. Mar. Drugs 10, 604-616. doi: 10.3390/md10030604

Duarte, C. M. (1992). Nutrient concentration of aquatic plants: patterns across species. Limnol. Oceanogr. 37, 882-889. doi: 10.4319/lo.1992.37.4.0882

Duarte, C. M., and Cebrian, J. (1996). The fate of marine autotrophic production. Limnol. Oceanogr. 41, 1758-1766. doi: 10.4319/lo.1996.41.8.1758

Duarte, C. M., Holmer, M., Olsen, Y., Soto, D., Marbà, N., Guiu, J., et al. (2009). Will the oceans help feed humanity? BioScience 59, 967-976. doi: 10.1525/bio.2009.59.11.8

Duarte, C. M., Losada, I. J., Hendriks, I. E., Mazarrasa, I., and Marbà, N. (2013). The role of coastal plant communities for climate change mitigation and adaptation. Nat. Clim. Change 3, 961-968. doi: 10.1038/nclimate1970

Duarte, C. M., Middelburg, J., and Caraco, N. (2005). Major role of marine vegetation on the oceanic carbon cycle. Biogeosciences 2, 1-8. doi: 10.5194/bg-2-1-2005

FAO (2016a). The State of World Fisheries and Aquaculture 2016. Contributing to Food Security and Nutrition for All. Rome: FAO.

FAO (2016b). "Fisheries and aquaculture software. FishStat Plus - Universal software for fishery statistical time series," in: FAO Fisheries and Aquaculture Department Rome. Updated 28 November 2013. Available online at: www.fao.org/fishery/statistics/software/fishstat/en (Accessed 22 November 2016).

Fernand, F., Israel, A., Skjermo, J., Wichard, T., Timmermans, K. R., and Golberg, A. (in press). Offshore macroalgae biomass for bioenergy production: Environmental aspects, technological achievements and challenges. Renew. Sustain. Energy Rev. doi: 10.1016/j.rser.2016.10.046

Fourqurean, J. W., Duarte, C. M., Kennedy, H., Marbà, N., Holmer, M., Mateo, M. A., et al. (2012). Seagrass ecosystems as a globally significant carbon stock. Nat. Geosci. 5, 505-509. doi: 10.1038/ngeo1477

Francavilla, M., Manara, P., Kamaterou, P., Monteleone, M., and Zabaniotou, A. (2015). Cascade approach of red macroalgae Gracilaria gracilis sustainable valorization by extraction of phycobiliproteins and pyrolysis of residue. Bioresource Technol. 184, 305-313. doi: 10.1016/j.biortech.2014.10.147

Fry, J. M., Joyce, P. J., and Aumonier, S. (2012). Carbon Footprint of Seaweed as a Biofuel. Prepared by Environmental Resources Management Limited (ERM), London for the Crown Estate, 64

Gattuso, J.-P., Gentili, B., Duarte, C. M., Kleypas, J. A., Middelburg, J. J., and Antoine, D. (2006). Light availability in the coastal ocean: impact on the distribution of benthic photosynthetic organisms and their contribution to primary production. Biogeosciences 3, 489-513. doi: 10.5194/bg-3-489-2006

Gattuso, J. P., Magnan, A., Billé, R., Cheung, W. W. L., Howes, E. L., Joos, F., et al. (2015). Contrasting futures for ocean and society from different anthropogenic $\mathrm{CO}_{2}$ emissions scenarios. Science 349:aac4722. doi: 10.1126/science.aac4722

Gaylord, B., Rosman, J. H., Reed, D. C., Koseff, J. R., Fram, J., and MacIntyre, S., et al. (2007). Spatial patterns of flow and their modification within and around a giant kelp forest. Limnol. Oceanogr. 52, 1838-1852. doi: 10.4319/lo.2007.52.5.1838

Gimpel, A., Stelzenmüller, V., Grote, B., Buck, B. H., Floeter, J., Núñez-Riboni, I., et al. (2015). A GIS modelling framework to evaluate marine spatial planning scenarios: Co-location of offshore wind farms and aquaculture in the German EEZ. Mar. Policy 55, 102-115. doi: 10.1016/j.marpol.2015.01.012

Harley, C. D. G., Anderson, K. M., Demes, K. W., Jorve, J. P., Kordas, R. L., Coyle, T. A., et al. (2012). Effects of climate change on global seaweed communities. J. Phycol. 48, 1064-1078. doi: 10.1111/j.1529-8817.2012.01224.x

Herrero, M., and Ibáñez, E. (2015). Green processes and sustainability: an overview on the extraction of high added-value products from seaweeds and microalgae. J. Supercrit. Fluids 96, 211-216. doi: 10.1016/j.supflu.2014.09.006

Hill, R., Bellgrove, A., Macreadie, P. I., Petrou, K., Beardall, J., Steven, A., et al. (2015). Can macroalgae contribute to blue carbon? An Australian perspective. Limnol. Oceanogr. 60, 1689-1706. doi: 10.1002/lno.10128

Hurd, C. L. (2015). Slow-flow habitats as refugia for coastal calcifiers from ocean acidification. J. Phycol. 51, 599-605. doi: 10.1111/jpy.12307

IPCC (2014). "Summary for policymakers," in Climate Change 2014: Impacts, Adaptation, and Vulnerability. Part A: Global and Sectoral Aspects. Contribution of Working Group II to the Fifth Assessment Report of the Intergovernmental Panel on Climate Change, eds C. B. Field, V. R. Barros, D. J. Dokken, K. J. Mach, M. D. Mastrandrea, T. E. Bilir, M. Chatterjee, K. L. Ebi, Y. O. Estrada, R. C. Genova, B. Girma, E. S. Kissel, A. N. Levy, S. MacCracken, P. R. Mastrandrea, and L.L. White (Cambridge, UK; New York, NY: Cambridge University Press), $1-32$.

Kaspersen, B. S., Christensen, T. B., Fredenslund, A. M., Møller, H. B., Butts, M. B., Jensen, N. H., et al. (2016). Linking climate change mitigation and coastal eutrophication management through biogas technology: evidence from a new Danish bioenergy concept. Sci. Total Environ. 541, 1124-1131. doi: 10.1016/j.scitotenv.2015.10.015

Keeling, R. F., Körtzinger, A., and Gruber, N. (2010). Ocean deoxygenation in a warming world. Mar. Sci. 2, 199-229. doi: 10.1146/annurev.marine.010908. 163855

Kerrison, P. D., Stanley, M. S., Edwards, M. D., Black, K. D., and Hughes, A. D. (2015). The cultivation of European kelp for bioenergy: Site and species selection. Biomass Bioenerg. 80, 229-242. doi: 10.1016/j.biombioe.2015.04.035

Kinley, R. D., de Nys, R., Vucko, M. J., Machado, L., and Tomkins, N. W. (2016). The red macroalgae Asparagopsis taxiformis is a potent natural antimethanogenic that reduces methane production during in vitro fermentation with rumen fluid. Anim. Prod. Sci. 56, 282-228. doi: 10.1071/AN15576

Kraan, S. (2013). Mass-cultivation of carbohydrate rich macroalgae, a possible solution for sustainable biofuel production. Mitigation Adap. Strateg. Glob. Change 18, 27-46. doi: 10.1007/s11027-010-9275-5

Krause-Jensen, D., and Duarte, C. M. (2014). Expansion of vegetated coastal ecosystems in the future Arctic. Front. Mar. Sci. 1:77. doi: 10.3389/fmars.2014.00077

Krause-Jensen, D., and Duarte, C. M. (2016). Substantial role of macroalgae in marine carbon sequestration. Nat. Geosci. 9, 737-742. doi: 10.1038/NGEO2790

Krause-Jensen, D., Duarte, C. M., Hendriks, I. E., Meire, L., Blicher, M. E., Marbà, N., et al. (2015). Macroalgae contribute to nested mosaics of $\mathrm{pH}$ variability in a sub-Arctic fjord. Biogeoscience 12, 4895-4911. doi: 10.5194/bg-12-4895-2015

Krause-Jensen, D., Marbà, N., Sanz-Martin, M., Hendriks, I. E., Thyrring, J., Carstensen, J., et al. (2016). Long photoperiods sustain high pH in Arctic kelp forests. Sci. Adv. 2:e1501938. doi: 10.1126/sciadv.1501938

Kronen, M., Ponia, B., Pickering, T., Teitelbaum, A., Meloti, A., Kama, J., et al. (2013). Social and economic dimensions of carrageenan seaweed farming in Solomon Islands. Social and economic dimensions of carrageenan seaweed farming. Fish. Aqua. Tech. Paper 580, 147-161.

Lehahn, Y., Ingle, K. N., and Golberg, A. (2016). Global potential of offshore and shallow waters macroalgal biorefineries to provide for food, chemicals and energy: feasibility and sustainability. Algal Res. 17, 150-160. doi: 10.1016/j.algal.2016.03.031

Lorbeer, A. J., Lahnstein, J., Bulone, V., Nguyen, T., and Zhang, W. (2015). Multiple-response optimization of the acidic treatment of the brown alga Ecklonia radiata for the sequential extraction of fucoidan and alginate. Bioresour. Technol. 197, 302-309. doi: 10.1016/j.biortech.2015.08.103

Løvås, S. M., and Tørum, A. (2001). Effect of the kelp Laminaria hyperborea upon sand dune erosion and water particle velocities. Coast. Eng. 44, 37-63. doi: 10.1016/S0378-3839(01)00021-7 
Machado, L., Magnusson, M., Paul, N. A., Kinley, R., de Nys, R., and Tomkins, N. (2016). Dose-response effects of Asparagopsis taxiformis and Oedogonium sp. on in vitro fermentation and methane production. J. Appl. Phycol. 28, 1443-1452. doi: 10.1007/s10811-015-0639-9

Maia, M. R. G., Fonseca, A. J. M., Oliveira, H. M., Mendonca, C., and Cabrita, A. R. J. (2016). The potential role of seaweeds in the natural manipulation of rumen fermentation and methane production. Sci. Rep. 6:32321. doi: 10.1038/srep32321

Mak, W., Wang, S. K., Liu, T., Hamid, N., Li, Y., Lu, J., et al. (2014). Anti-proliferation potential and content of fucoidan extracted from sporophyll of New Zealand Undaria pinnatifida. Front. Nutr. 1:9. doi: 10.3389/fnut.2014.00009

Makkar, H. P., Tran, G., Heuzé, V., Giger-Reverdin, S., Lessire, M., Lebas, F., et al. (2016). Seaweeds for livestock diets: a review. Anim. Feed Sci. Technol. 212, 1-17. doi: 10.1016/j.anifeedsci.2015.09.018

Martínez, E., Sanz, F., Pellegrini, S., Jiménez, E., and Blanco, J. (2009). Life cycle assessment of a multi-megawatt wind turbine. Renewable Energy 34, 667-673. doi: 10.1016/j.renene.2008.05.020

Masarin, F., Cedeno, F. R. P., Chavez, E. G. S., Oliveira, L. E., Gelli, V. C., and Monti, R. (2016). Chemical analysis and biorefinery of red algae Kappaphycus alvarezii for efficient production of glucose from residue of carrageenan extraction process. Biotechnol. Biofuels 9:122. doi: 10.1186/s13068-016-0535-9

Mazarrasa, I., Olsen, Y. S., Mayol, E., Marbà, N., and Duarte, C. M. (2014). Global unbalance in seaweed production, research effort and biotechnology markets. Biotechnol. Adv. 32, 1028-1036. doi: 10.1016/j.biotechadv.2014.05.002

McLaughlan, C., Gallardo, B., and Aldridge, D. C. (2014). How complete is our knowledge of the ecosystem services impacts of Europe's top 10 invasive species? Acta Oecol. 54, 119-130. doi: 10.1016/j.actao.2013.03.005

McLeod, E., Chmura, G. L., Bouillon, S., Salm, R., Björk, M., Duarte, C. M., et al. (2011). A blueprint for blue carbon: towards an improved understanding of the role of vegetated coastal habitats in sequestering $\mathrm{CO}_{2}$. Front. Ecol. Environ. 9, 552-560. doi: 10.1890/110004

Middelboe, A. L., and Hansen, P. L. (2007). High pH in shallow-water macroalgal habitats. Mar. Ecol. Prog. Ser. 338, 107-117. doi: 10.3354/meps33810

Moreira, D., and Pires, J. C. (2016). Atmospheric $\mathrm{CO}_{2}$ capture by algae: negative carbon dioxide emission path. Bioresour. Technol. 215, 371-379. doi: 10.1016/j.biortech.2016.03.060

Mork, M. (1996). "Wave attenuation due to bottom vegetation," in Waves and Nonlinear Processes in Hydrodynamics, eds J. Grue, B. Gjevik, and J. E. Weber (Oslo: Kluwer Academic Publishing), 371-382.

Msuya, F. E. (2011). The impact of seaweed farming on the socioeconomic status of coastal communities in Zanzibar, Tanzania. World Aquaculture 42, 45-48.

Nellemann, C., Corcoran, E., Duarte, C. M., Valdés, L., De Young, C., and Fonseca, L., et al. (eds.). (2009). Blue Carbon. A Rapid Response Assessment. United Nations Environment Programme. Birkeland: GRID-Arendal. Available online at: www.grida.no

O’Doherty, J. V., Dillon, S., Figat, S., Callan, J. J., and Sweeney, T. (2010). The effects of lactose inclusion and seaweed extract derived from Laminaria spp. on performance, digestibility of diet components and microbial populations in newly weaned pigs. Anim. Feed Sci. Technol. 157, 173-180. doi: 10.1016/j.anifeedsci.2010.03.004

Olafsen, T., Winther, U., Olsen, Y., and Skjermo, J. (2012). Value Created from Productive Oceans in 2050. DKNVS and NTVA.

O'Shea, C. J., McAlpine, P., Sweeney, T., Varley, P. F., and O'Doherty, J. V. (2014). Effect of the interaction of seaweed extracts containing laminarin and fucoidan with zinc oxide on the growth performance, digestibility and faecal characteristics of growing piglets. Br. J. Nutr. 111, 798-807. doi: $10.1017 /$ S0007114513003280

Radulovich, R., Umanzor, S., Cabrera, R., and Mata, R. (2015). Tropical seaweeds for human food, their cultivation and its effect on biodiversity enrichment. Aquaculture 436, 40-46. doi: 10.1016/j.aquaculture.2014.10.032

Ramankutty, N., Evan, A. T., Monfreda, C., and Foley, J. A. (2008). Farming the planet: 1. Geographic distribution of global agricultural lands in the year 2000 . Glob. Biogeochem. Cycles 22:GB1003. doi: 10.1029/2007GB002952

Rebours,. C., Marinho-Soriano, E., Zertuche-González, J., Hayashi, L., Vásquez, J., Kradolfer, P., et al. (2014). Seaweeds: an opportunity for wealth and sustainable livelihood for coastal communities. J. Appl. Phycol. 26, 1939-1951. doi: 10.1007/s10811-014-0304-8
Rey-Crespo, F., Lopez-Alonso, M., and Miranda, M. (2014). The use of seaweed from the Galician coast as a mineral supplement in organic dairy cattle. Animal 8, 580-586. doi: 10.1017/s1751731113002474

Roberts, D. A., Paul, N. A., Dworjanyn, S. A., Bird, M. I., and de Nys, R. (2015). Biochar from commercially cultivated seaweed for soil amelioration. Sci. Rep. 5:9665. doi: 10.1038/srep09665

Robertson, G. P., Paul, E. A., and Harwood, R. R. (2000). Greenhouse gases in intensive agriculture: contributions of individual gases to the radiative forcing of the atmosphere. Science 289, 922-1925. doi: 10.1126/science.289.5486.1922

Robledo, D., Gasca-Leyva, E., and Fraga, J. (2013). "Social and economic dimensions of carrageenan seaweed farming in Mexico," in Social and Economic Dimensions of Carrageenan Seaweed Farming, Fisheries and Aquaculture, Technical Paper No. 580, eds D. Valderrama, J. Cai, N. Hishamunda and N. Ridler (Rome: FAO), 185-204.

Seghetta, M., Tørring, D., Bruhn, A., and Thomsen, M. (2016). Bioextraction potential of seaweed in Denmark - An instrument for circular nutrient management. Sci. Total Environ. 563-564, 513-529. doi: 10.1016/j.scitotenv.2016.04.010

Skjermo, J., Rebours, C., and Chapman, A. (2014). A New Norwegian Bioeconomy Based on Cultivation and Processing of Seaweeds: Opportunities and RひD Needs. Trondheim: SINTEF Fisheries and Aquaculture. SINTEF A25981.

Smale, D. A., Burrows, M. T., Moore, P., O'Connor, N., and Hawkins, S. J. (2013). Threats and knowledge gaps for ecosystem services provided by kelp forests: a northeast Atlantic perspective. Ecol. Evol. 3, 4016-4038. doi: 10.1002/ece3.774

Smith, B. E. (2002). Nitrogenase reveals its inner secrets. Science 297, 1654-1655. doi: 10.1126/science.1076659

Sondak, C. F., and Chung, I. K. (2015). Potential blue carbon from coastal ecosystems in the Republic of Korea. Ocean Sci. J. 50, 1-8. doi: 10.1007/s12601-015-0001-950(1)

Steneck, R. S., Graham, M. H., Bourq, B. J., Corbett, D., and Erlandson, J. M. (2002). Kelp forest ecosystems, biodiversity, stability resilience and future. Environ. Conserv. 29, 436-459. doi: 10.1017/S0376892902000322

Stévant, P., Rebours, C., and Chapman, A. (2017). Seaweed aquaculture in Norway: recent industrial developments and future perspectives. Aquacult. Internat. 1-18. doi: 10.1007/s10499-017-0120-7

Sulaiman, O. O., Kader, A. S. A., Magee, A., and Othman, K. (2015). Mooring analysis of offshore aquaculture oceanic farming platform for seaweed. J. Coast Zone Manag. 18:399. doi: 10.4172/2473-3350.1000399

The Fishery Bureau MoA. (2015). China Fishery Statistical Yearbook. Beijing: China Agriculture Press.

Trevathan-Tackett, S. M., Kelleway, J., Macreadie, P. I., Beardall, J., Ralph, P., and Bellgrove, A. (2015). Comparison of marine macrophytes for their contributions to blue carbon sequestration. Ecology 96, 3043-3057. doi: 10.1890/15-0149.1

Waycott, M., Duarte, C. M., Carruthers, T. J., Orth, R. J., Dennison, W. C., Olyarnik, S., et al. (2009). Accelerating loss of seagrasses across the globe threatens coastal ecosystems. Proc. Natl. Acad. Sci. U.S.A. 106, 12377-12381. doi: 10.1073/pnas.0905620106

Zacharia, P. U., Kaladharan, P., and Rohith, G. (2015). "Seaweed farming as a climate resilient strategy for Indian coastal waters," in The International Conference on Integrating Climate, Crop, Ecology - The Emerging Areas of Agriculture, Horticulture, Livestock, Fishery, Forestry, Biodiversity, and Policy Issues (New Delhi).

Zhang, J., Fang, J., Wang, W., Du, M., Gao, Y., and Zhang, M. (2012). Growth and loss of mariculture kelp Saccharina japonica in Sungo Bay, China. J. Appl. Phycol. 24, 1209-1216. doi: 10.1007/s10811-011-9762-4

Conflict of Interest Statement: The authors declare that the research was conducted in the absence of any commercial or financial relationships that could be construed as a potential conflict of interest.

Copyright (c) 2017 Duarte, Wu, Xiao, Bruhn and Krause-Jensen. This is an openaccess article distributed under the terms of the Creative Commons Attribution License (CC BY). The use, distribution or reproduction in other forums is permitted, provided the original author(s) or licensor are credited and that the original publication in this journal is cited, in accordance with accepted academic practice. No use, distribution or reproduction is permitted which does not comply with these terms. 